\title{
A Modest Experiment in Pedagogy: Lessons on Comparative Constitutional Law
}

Thomas E. Baker

Florida International University College of Law

Follow this and additional works at: https://ecollections.law.fiu.edu/faculty_publications

Part of the Comparative and Foreign Law Commons, and the Constitutional Law Commons

\section{Recommended Citation}

Thomas E. Baker, A Modest Experiment in Pedagogy: Lessons on Comparative Constitutional Law, 6 F.I.U. L. Rev. 99 (2012) 


\section{HEINONLINE}

Citation: 6 FIU L. Rev. 99 2010-2011

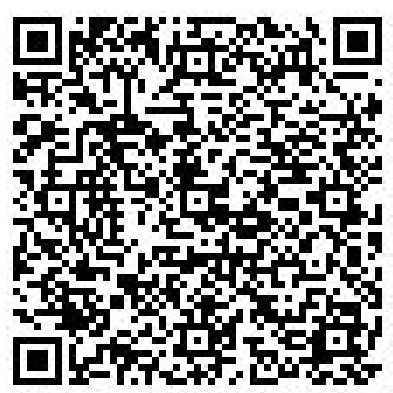

Content downloaded/printed from

HeinOnline (http://heinonline.org)

Tue Mar 4 10:59:44 2014

-- Your use of this HeinOnline PDF indicates your acceptance of HeinOnline's Terms and Conditions of the license agreement available at http://heinonline.org/HOL/License

-- The search text of this PDF is generated from uncorrected OCR text. 


\title{
A Modest Experiment in Pedagogy: Lessons on Comparative Constitutional Law
}

\author{
Thomas E. Baker
}

\begin{abstract}
This article has been revised from a paper I presented and submitted to the International Association of Law Schools Conference on Comparative Constitutional Law, Washington, D.C. (Sept. 11-12, 2009) hosted by the American University Washington College of Law and the Georgetown University Law Center. That invitational conference - I was invited as one of the representatives of the United States - brought together an amazing array of leading constitutionalists from all over the world. This article describes how I have integrated comparative and international law lessons into my basic, first year course on U.S. Constitutional Law. This version of the paper reflects my experience at that Conference and the comments of the other participants. I have also added citations and quotations to the relevant papers of other conference participants to make this version of the paper all the more thoughtful and helpful. The article includes: a brief review of the secondary literature on teaching comparative constitutional law; a bibliography of comparative constitutional law books; a basic pedagogical theory; some practical advice and recommendations; and a set of four lessons on the themes of judicial review, transnational interpretation, affirmative action, and reproductive rights, complete with discussion questions and a list of readings.
\end{abstract}

$$
* * *
$$

\footnotetext{
* Professor of Law, Florida International University College of Law, Miami, Florida (http://law.fiu.edu/; thomas.baker@fiu.edu). This article was originally written and submitted to the International Association of Law Schools Conference on Comparative Constitutional Law, Washington, D.C. (Sept. 11-12, 2009), http:/www.ialsnet.org/meetings/constit/papers/ BakerThomas(USA).pdf, hosted by the American University Washington College of Law and the Georgetown University Law Center, http:/www.ialsnet.org/meetings/constit/papers/ MasterBookletConLaw.pdf. The author is grateful for the thoughtful reactions of his fellow conferees. An evolved version of this paper was presented at the Annual Meeting of the World Institute for Research and Publication - Constitutional Law (May 14-16, 2010), http://www.wirp.org/law. The author likewise is grateful to Professor Allesandra Rinaldi, General Secretary of the Institute, and to our fellow online conferees for their thoughtful audience reactions.
} 
In 2002, when I joined the founding faculty at the Florida International University College of Law, I had been teaching constitutional law for over two decades. I prided myself on being an innovative teacher who was willing to try new and different approaches.' Like many American law professors, however, I was agnostic about comparative and international law. I had grown accustomed to teaching a traditional course, using a traditional casebook, following a traditional design albeit with the occasional filigree. ${ }^{2}$ My no-nonsense syllabus promised:

Our course goal is to achieve the basic understanding of modern constitutional law that is necessary to be a successful law student, an able lawyer, and a good citizen. The objects of our study are the Constitution and the Supreme Court. This is a course in "con law for lawyers" - we will read, analyze, and argue about constitutional law the way lawyers and judges do. ${ }^{3}$

As its name suggests, the University I joined was originally chartered to promote international understanding. ${ }^{4}$ Its stated mission is to be "an urban, multi-campus, research university serving South Flori$\mathrm{da}$, the state, the nation and the international community [that] impart[s] knowledge through excellent teaching, promoting public service, discovering new knowledge, solving problems through research, and fostering creativity." FIU has long been committed to the idea of

1 See, e.g., Thomas E. Baker, A Law Student's Responsibility for a Liberal Education, 20 TEX. TECH L. REV. 1153 (1989); Thomas E. Baker \& James E. Viator, Not Another Constitutional Law Course: A Proposal to Teach a Course on the Constitution, 76 IOWA L. REv. 739 (1991); Thomas E. Baker, Teaching a Course on the Constitution - Finding and Using Founding Documents; Casebook and Supplement; Internet Sites Can Make a Web-Based Course, Using Quizzes, Opinion Writing Assignment, in TEACHING THE LAw SchoOl CuRriculum (Steven Friedland \& Gerald F. Hess eds., 2004).

2 See generally Thomas E. Baker, Mastering Modern Constitutional Law, 21 SEATTLE U.L. REV. 927 (1998) (describing some of the filigrees I add to RONALD D. ROTUNDA, MODERN CONSTITUTIONAL LAW: CASES AND NOTES (9th ed. 2009)).

3 The best single volume on designing a law school course is MICHAEL HUNTER Schwartz, Sophie Sparrow \& Gerald Hess, Teaching Law By Design (2009). See Thomas E. Baker \& Mary Olszewska, An Annotated Bibliography on Law Teaching, 18 PERSP.: TEACHING LEGAL RES. \& WRITING 34 (2009).

4 Florida international University - MillenniUm Strategic Plan 12 (2002), http://www.fiu.edu/oir/docs/msp.pdf. The student body of the College of Law, in turn, is remarkably international. A few years ago, a colleague took a census in his first year class of approximately sixty students; he learned that they were born in twenty-five different countries (Argentina, the Bahamas, Brazil, Canada, Colombia, Cuba, the Czech Republic, Haiti, Honduras, India, Italy, Iraq, Iran, Jamaica, Japan, Mexico, the Netherlands, Pakistan, Peru, Russia, Trinidad-Tobago, Turkey, Ukraine, Venezuela, and Yugoslavia) and some of the countries on the list (e.g., Cuba) were the birthplace of multiple students. Email from Andrew Jay McClurg to Thomas E. Baker (Dec. 12, 2009) (on file with the author).

5 Florida International University Mission Statement, http://academic.fiu.edu/ provost_mission.html (last visited Apr. 13, 2011). 
globalism and has achieved considerable distinction in the social sciences and the international realm, through its programs, centers, and institutes. ${ }^{6}$

The College of Law is contributing to that institutional prominence. ${ }^{7}$ We understand that our students will practice law in an increasingly globalized professional reality - their "real world" will be the "entire world." Our College's mission statement provides, in part:

The College of Law offers a curriculum that prepares students for ethical and effective practice of law in an increasingly global and multicultural world. The curriculum includes a full and faithful presentation of the courses traditionally offered at nearly all U.S. law schools. In addition, building on the parent university's distinction in its international programs, the curriculum incorporates important developments in the globalization of both public and private law. The academic program takes a pervasive approach to international and comparative law, incorporating these perspectives into all domestic law classes, and includes a required introductory course and a rich array of upper level electives in international, transnational and comparative law.

We have kept each of these curricular promises. First, we created a hybrid course that is unique in American legal education: "Introduction to Comparative and International Law," a three-hour required first-year course offered in the spring semester. ${ }^{10}$. Second, like most

\footnotetext{
6 See generally MILlenNiUm StRategic Plan, supra note 4, at 12-16.

7 Thomas E. Baker, Reflections on Law Schools and the Idea of the University, 1 FIU L. REV. 1 (2006).

8 See generally Japp Hage, Comparative Law and Legal Science (Maastricht European Private Law Institute, Working Paper No. 2011/11,2011), available at http://ssrn.com/ abstract=1600108; Lawrence M. Friedman, Borders: On the Emerging Sociology of Transnational Law, 32 STAN. J. INT'L L. 65 (1996); Mark C. Rahdert, Comparative Constitutional Advocacy, 56 AM. U. L. REv. 553 (2007); Laurel S. Terry, et al., Transnational Legal Practice, 43 INT'L LAWYER 943 (2009); John E. Sexton, Curricular Responses to Globalization, 20 PENN. ST. INT'L L. REV. 15, 17 (2001); Report Regarding the Pacific McGeorge Workshop on Globalizing the Law School Curriculum, 19 PAC. MCGeorge GlobAL BUS. \& DEV. L.J. 267, 286-92 (2006).

9 FIU College of Law Faculty Bylaws, Part I. at 5 (Mar. 2, 2007).

10 The course catalogue description reads:

Law 5259. Introduction to International and Comparative Law. This new course introduces students to public international law, international economic law, and comparative law. Exposure to the law of nations in the international component of the course poses critical jurisprudential questions on the nature of law, the role of enforceability, and the prospects for constructing an international society. The comparative component compares and contrasts the common law system that prevails in the United States to civil law systems, especially as they have evolved in Latin America. Together the course provides the foundation for later advanced study in these and other topics as part of the upper level curriculum.
} 
other American law schools, our curriculum presents a menu of advanced, elective courses in international and comparative law. ${ }^{11}$ Third, the corporate faculty has committed to "globalizing, internationalizing, trans-nationalizing, and comparativizing" the legal education we provide our students pervasively, i.e., in every course we teach. $^{12}$ Our Faculty Bylaw on teaching explicitly requires: "Each faculty member must be committed to excellence in fulfilling teaching responsibilities, and, consistent with the mission of the College of Law, devote a minimum of one class hour per course credit hour to coverage of relevant international and comparative law materials in their domestic law classes, except seminars."13

In the rest of this paper, I will explain how I meet this obligation in my first-year, first semester four-hour required course on constitutional law. ${ }^{14}$ The general advice I would offer my reader would be to

CATAlogue of THE Florida INTERNATIONAL UNiversity COLlEgE of LAW 28 (2008-09). For an account of the curious conceptual origins of this course, which sprang from the imagination of our founding dean like Pallas Athena sprang from the forehead of Zeus, see generally Leonard P. Strickman, A New Law School: An International Curriculum, 43 S. TEX. L. REV. 641, 643-44 (2002).

11 A sample list of these courses includes: Admiralty Law; Caribbean Law and Development; Comparative Business Law; Comparative Constitutional Law; Comparative Criminal Law; Comparative Environmental Law Urban Issues; Comparative Family Law; Comparative Law; Comparative Law: Constitutions and the Judicial Process; Comparative Perspectives on the Regulatory State; Conflict Management Practice-Comparative Perspective of Mediation; Conflict Management Practice-Comparative Perspectives of Negotiation; Conflict Prevention and Community Improvement; Conflicts of Law; Cross Cultural Communication in International Dispute Resolution; Environmental Health Law and Policy; European Union Law; Foreign Relations and National Security Law; Immigration and Human Rights Clinic; Immigration Law; International and Comparative Sales; International Antitrust; International Banking; International Business Transactions; International Commercial Arbitration; International Criminal Law; International Environmental Law; International Human Rights Law; International Intellectual Property Law; International Litigation; International Organizations; International Taxation; International Telecommunications Law; International Trade Law and Policy; Introduction to International and Comparative Law; Latin American Private Law; Law and Politics in Latin America; NAFTA and Other Regional Trade Agreements; Ocean and Coastal Law; Payment Systems; Profesión Jurídica Comparada (Comparative Legal Profession); Public International Law; Refugee and Asylum Law; and Transnational Commercial Law. See FIU Law: International and Comparative Law, http://law.lawnet.fiu.edu/index.php?option=com_content\&task= view\&id=64\&Itemid= 613 (last visited Apr. 13, 2011).

12 M.C. Mirow, Globalizing Property: Incorporating Comparative and International Law into First-Year Property, 54 J. LEGAL EduC. 183, 186 (2004). See Brian K. Landsberg (McGeorge School of Law, U.S.A.), The Use of International and Comparative Sources in a Domestic Constitutional Law Course, International Association of Law Schools Conference on Constitutional Law, Washington, D.C. (Sept. 11-14, 2009), http:/www.ialsnet.org/meetings/ constit/papers/LandsbergBrian (USA).pdf (the coeditor of a global series of course supplements describes the "pervasive" approach).

13 FIU College of Law Faculty Bylaws, Part III. B (1) at 10 (Mar. 2, 2007).

14 The course description of the course provides: 
repeat the same expert advice of others whom I have benefited from following. First, my approach was "selective and modest" - a selfconsciously tentative attempt to expose my novice students to my own novice comparativist perspectives. ${ }^{15}$ After all, my students are enrolled in an introductory survey course on American constitutional law, not an advanced comparative law course, and I myself am not a comparativist. Second, I sought to "identify practices or doctrines in other stable democracies that are different from those in the United States, and ask: They do things differently there. What reasons might they have for adopting their practices or doctrines? What reasons might there be that caution against our adopting those practices or doctrines?"'16 Finally, I set out to explore with my students some interesting examples of a phenomenon Justice Breyer so aptly but obliquely once described: how and why "[j]udges in different countries increasingly apply somewhat similar legal phrases to somewhat similar circumstances." 17 These three recommendations have served me and my students very well.

After consulting some of the excellent teaching resources available, ${ }^{18}$ I developed four thematic "Lessons on Comparative Constitu-

Law 5501. Constitutional Law (4 credits): This course deals with the fundamental principles of American constitutionalism. It considers the relationships between the branches of the federal government within the separation of powers and the relationship of the national government with the states within our federalism. It focuses on the institution of the Supreme Court and its power of judicial review and how that power is exercised to interpret the Constitution. The various powers of Congress are studied, especially the commerce clause power, including its negative effects on the state police power. The executive powers of the President, both domestic and foreign, are explored. The constitutional relationship between the individual and the government is analyzed within the context of the due process and equal protection clauses of the fourteenth amendment.

CATALOGUE OF THE FLORIDA INTERNATIONAL UNIVERSITY COLLEGE OF LAW 28 (2008-09).

15 Neil S. Siegel, Some Modest Uses of Transnational Legal Perspectives in First-Year Constitutional Law, 56 J. LEGAL EDUC. 201, 201 (2006) ("Selectivity and modesty are warranted.").

16 Mark Tushnet, How (and How Not) to Use Comparative Constitutional Law in Basic Constitutional Law Courses, 49 ST. LOUIS U. L.J. 671, 674 (2005).

17 David S. Law, Generic Constitutional Law, 89 MINN. L. REV. 652, 661 (2005) quoting Stephen Breyer, The Supreme Court and the New International Law (ASIL Annual Meeting Apr. 4, 2003).

18 E.g., Global Perspectives on CONSTitutional Law (Vikram David Amar \& Mark V. Tushnet eds., 2009); MICHAEL Louis CORRADO, COMPARATIVE CONSTITUTIONAL REVIEW: Cases and Materials (2005); Norman Dorsen et al., Comparative Constitutionalism: Cases and Materials (2003); Vicki C. JaCKSON \& Mark Tushnet, Comparative COnstitutional LAW (2d ed. 2006); DEFining THE Field of Comparative CONSTTTUTIONAL LAW (Vicki C. Jackson \& Mark Tushnet eds., 2002); BRIAN LANDSBERG \& LeSliE Jacobs, Global ISSUES in CONSTITUTIONAL LAW: CASES AND MATERIALS (2007); Francois Venter, Constitutional Comparison: JAPAN, Germany, Canada \& SOUTH AFRICA AS CONSTITUTIONAL STATES (2000). There are numerous recent books that can be mined for interesting teaching materials for a beginning student. A good example is the Hart Publishing Company's series on "Constitutions of the World"; each volume deals with a differ- 
tional Law." ${ }^{19}$ Each is a self-contained unit consisting of a brief introduction, some general discussion questions, links to assigned readings, and a list of recommended further readings. ${ }^{20}$ In the manner of a bricoleur, ${ }^{21}$ I assembled the readings for the Lessons, other background materials including video recordings of relevant programs and lectures, and links to relevant documents and accompanying sites for my students to access on the user-friendly West Educational Network ("TWEN"). ${ }^{2}$ My Lessons are admittedly derivative of the work of others. I will only briefly describe them here; the interested reader can examine the actual Lessons reproduced in the Appendix to this article.

Lesson I: Judicial Review. After covering the introductory chapter with the traditional cases on the power of judicial review and its limitations, students first read a traditional descriptive account of how judicial review spread throughout the world, especially in the second

ent country and each author is an expert in the field. Hart Publishing: Constitutional Systems of the World, http:/www.hartpub.co.uk/books/series.asp?sc=Constitutional+Systems+of+the+ World\&st=Constitutional+Systems+of +the+World (last visited Apr. 13, 2011).

19 See Philipp Kiiver \& Mariolina Eliantonio (Maastricht University, The Netherlands), Teaching Comparative Constitutional Law: Methodological Challenges, International Association of Law Schools Conference on Constitutional Law, Washington, D.C. (Sept. 11-14, 2009), http:/www.ialsnet.org/meetings/constit/papers/Eliantonio\&Kiiver(thenetherlands).pdf (evaluating the two competing approaches of teaching comparative constitutional law on a country-bycountry basis versus a comparison subject-by-subject basis).

20 Of course, during the semester I also make numerous interspersed references and comments to comparative constitutional law that are brief and specific, often of a current-event nature. See Mark S. Kende (Drake University, U.S.A.), Teaching Comparative Perspectives in the Domestic Constitutional Law Class: a Step by Step Primer, International Association of Law Schools Conference on Constitutional Law, Washington, D.C. (Sept. 11-14, 2009), http://www.ialsnet.org/meetings/constit/papers/KendeMark(USA).pdf.

21 The process I call bricolage is perhaps the method least familiar to U.S. constitutional scholars. Describing a people she studied who annoyingly seemed to appropriate elements of its culture from anything at hand, Margaret Mead wrote, "A picture of a local native reading the index to the Golden Bough just to see if they had missed anything, would be appropriate." Claude Levi-Strauss called this sort of activity bricolage, the assembly of something new from whatever materials the constructor discovered. Contemporary references to comparative constitutional materials may be a form of bricolage. Functionalists and expressivists worry about whether appropriating selected portions of other constitutional traditions is sensible, or whether the appropriation will "work" in some sense. The bricoleur does not have these concerns about maintaining proper borders among systems.

Mark Tushnet, The Possibilities of Comparative Constitutional Law, 108 YALE LJ. 1225, 1229 (1999) (footnotes omitted).

22 E.g., A Conversation on the Relevance of Foreign Law for American Constitutional Adjudication with U.S. Supreme Court Justices Antonin Scalia \& Stephen Breyer, American University (Jan. 13, 2005), http://www.wcl.american.edu/secle/founders/2005/050113.cfm; Center for Comparative Constitutionalism, http://ccc.uchicago.edu/links.html; Comparative Constitutions Project, http://www.comparativeconstitutionsproject.org/; Concourts.net - comparative constitutional analysis, http:/www.concourts.net/; Constitution Finder, http:/confinder.richmond.edu/; International Constitutional Law Project, http://www.servat.unibe.ch/icl/info.html. 
half of the twentieth century, ${ }^{23}$ and then they read Ran Hirschl's critique of that development from the perspective of critical theory. ${ }^{24}$ Discussion questions include: What difference has the power of judicial review made in the constitutional history of the United States and other countries? What explains a country's attitudes towards its judicial institutions, i.e., courts, judges and the exercise of judicial review? Can other institutions of government besides the judiciary define and protect individual rights? What are the relative institutional advantages and disadvantages of the traditional three branches - Legislative, Executive, and Judicial - for interpreting the Constitution? How have different countries sought to adjust for the "countermajoritarian" difficulty of the doctrine of judicial review?

Lesson II: Transnational Interpretation. Law students today are familiar with the concept of globalization and how transnational influences transcend national boundaries and influence matters of culture and economics. Certainly, the popular culture of the United States is a significant influence around the world. Indeed, the phenomenon of "Americanization" has been derisively dubbed "McWorld." Students are asked to apply these ideas to constitutional law. Can it be imported and exported from one country to another or is a particular country's fundamental law unique - exclusive and self-contained to that country? The required readings include an article by now former Puisne Justice L'Heureux-Dube of the Supreme Court of Canada, in which she criticizes the Rehnquist Court for not engaging in the international judicial dialogue on comparative constitutional law, ${ }^{25}$ and a case in which the Justices argue over the propriety of importing constitutional law into the United States. ${ }^{26}$ This Lesson comes after students have been exposed to the deep structure of the Constitution, i.e., separation of powers and federalism, and after they have carefully parsed judicial opinions that self-consciously apply constitutional hermeneutics.

23 William E. NELSON, The Worldwide Spread of Judicial Review, in MARBURY $V$. MADISON: THE ORIGINS AND LEGACY OF JUDICIAL REVIEW 104-13 (2000).

24 Ran Hirschl, Looking Sideways, Looking Backwards, Looking Forwards: Judicial Review vs. Democracy in Comparative Perspective, 34 U. RICH. L. REV. 415 (2000); see also RAN Hirschl, Towards Juristocracy: The Origins and Consequences of the New CONSTITUTIONALISM (2004).

25 Clair L'Heureux-Dube, The Importance of Dialogue: Globalization and the International Impact of the Rehnquist Court, 34 TULSA L. J. 15 (1998).

26 Knight v. Florida, 528 U.S. 990 (1999); see also Henk Botha (University of Stellenbosch, South Africa), Foreign Constitutional Law and the Courts: Reflections from the South, International Association of Law Schools Conference on Constitutional Law, Washington, D.C. (Sept. 11-14, 2009), http:/www.ialsnet.org/ meetings/constit/papers/BothaHenk(SouthAfrica).pdf ("I know of no South African constitutional lawyer or commentator who would dispute that foreign law can - and often does - play a legitimate role in constitutional interpretation."). 
Lesson UII:Affirmative_Action. After completing their study of the Equal Protection Clause, students read about "special measures" referenced in the International Covenant on Civil and Political Rights, the International Convention on the Elimination of All Forms of Racial Discrimination, and the Convention on the Elimination of All Forms of Discrimination Against Women." In the United States, "special measures" are usually called "affirmative action" or "reverse discrimination." In the European Community, the term is "positive action." The programs are known in India as "compensatory discrimination." Students are asked to consider whether these government programs are permitted under the various international treaties and the domestic constitutional law of the relevant country. Students are expected to respond comparativistically: first from the perspective of the United States - based on their course study - and second from the different perspective of another country of their choosing based on their reading from an extensive list of country-specific articles. ${ }^{28}$

Lesson IV: Reproductive Rights. After we cover fundamental rights, including the right to privacy and sexual autonomy, ${ }^{29}$ students read the line of high court cases on abortion from either Canada ${ }^{30}$ or Germany. ${ }^{31}$ The obvious comparison, of course, is with the line of cases in U.S. Reports that includes Griswold, ${ }^{32}$ Roe, ${ }^{33}$ and Casey. ${ }^{34}$ We then discuss a hypothetical state Zero Population Growth Act, pat-

27 See generally Ruth Bader Ginsburg \& Deborah Jones Merritt, Affirmative Action: An International Human Rights Dialogue, 21 CARDozo L. REV. 253 (1999); see also Martha I. Morgan, (University of Alabama, U.S.A.), The Roles of International Human Rights Norms in Comparative Constitutional Jurisprudence: CEDAW-Based Examples, International Association of Law Schools Conference on Constitutional Law, Washington, D.C. (Sept. 11-14, 2009), http://www.ialsnet.org/ meetings/constit/papers/MorganMartha(USA).pdf (discussing the Convention on the Elimination of All Forms of Discrimination Against Women).

28 E.g., The Gender of Constitutional JuRisprudence (Beverley Baines \& Ruth Rubio-Marin eds., 2005) (comparing the constitutions of Australia, Canada, Colombia, Costa Rica, France, Germany, India, Israel, South Africa, Spain, Turkey, and the United States); Symposium on Affirmative Action: An International Perspective on a Global Dilemma, 36 ConN. L. REV. 649-877 (2004) (articles about the United States, South Africa, India, Brazil, and international human rights law).

29 See Martha F. Davis (Northeastern University, U.S.A) \& Bethany Withers (Harvard University, U.S.A), Reproductive Rights in the Legal Academy: A New Role for Transnational Law, International Association of Law Schools Conference on Constitutional Law, Washington, D.C. (Sept. 11-14, 2009), http://www.ialsnet.org/meetings/constit/papers/DavisMartha(USA).pdf.

30 Morgentaler, Smoling \& Scott v. The Queen, [1988] 1 S.C.R. 30 (Can.), redacted in JACKSON \& TUSHNET, supra note 18 , at $74-110$.

31 JACKSON \& TUSHNET, supra note 18, at 110-40 (redacting the 1975 West German Abortion Decision and the post-unification 1993 decision invalidating the subsequent statute the Bundestag enacted in 1990).

32 Griswold v. Connecticut, 381 U.S. 479 (1965) (right of marital privacy).

33 Roe v. Wade, 410 U.S. 113 (1973) (right of privacy/abortion).

34 Planned Parenthood of Se. Penn. v. Casey, 505 U.S. 833 (1992) (reaffirming Roe). 
terned after China's "One Child Rule," which would impose a twochild limitation on families for the stated purposes of preserving the quality of life in the state, slowing increased demand for state government services, and reducing environmental degradation.

As I remind my students, their study of comparative constitutional law helps them better understand U.S. constitutional law, not unlike how reading a concurring opinion or a dissenting opinion helps them better understand a majority opinion. Their engagement with the materials during class is gratifying. Preparation is evident. Participation is animated. Discussion often goes over the allotted class time and typically spills out into the hallway.

My students' engagement with the comparative constitutional law readings is part of their evaluation in the form of an essay paper, worth ten percent of their final course grade. Having been exposed to the ongoing debate among the current Justices of the Supreme Court of the United States whether comparative constitutional analysis is an appropriate and a legitimate aspect of American judicial review, ${ }^{35}$ they are required to take a side in this debate and write an essay to justify their position within the American judicial tradition. They are expected to consider and respond to the opposing arguments, as well, in a balanced and measured essay with examples. ${ }^{36}$ Their thoughtful essays are further evidence of how they have begun to appreciate a comparative constitutional law perspective.

Thus, by the completion of my introductory course on U.S. constitutional law, my $1 \mathrm{~L}$ students have begun to understand intuitively

35 See, e.g., Roper v. Simmons, 543 U.S. 551 (2005) (Kennedy, J., for the Court; O'Connor, J. \& Scalia, J., dissenting); Lawrence v. Texas, 539 U.S. 558 (2003) (Kennedy, J. for the Court; Scalia, J., dissenting); Grutter v. Bollinger, 539 U.S. 306, 344 (2003) (Ginsburg, J., concurring); Atkins v. Virginia, 536 U.S. 304, 321 (2002) (Rehnquist, C.J., dissenting); Foster v. Florida, 537 U.S. 990 (2002) (Thomas, J., concurring; Breyer, J., dissenting); Knight v. Florida, 528 U.S. 990 (1999) (Thomas, J., concurring; Breyer, J., dissenting); Printz v. United States, 521 U.S. 898, 921 n.11 \& 976 (1997) (Scalia, J., majority; Breyer, J., dissenting); Thompson v. Oklahoma, 487 U.S. 815, 830-32 \& 869 n.4 (1988) (Stevens, J., for the Court; Scalia, J., dissenting).

36 Discussion Questions include: Are constitutional provisions arbitrary political constructs that are idjosyncratic to a particular country and a particular era or are there background normative principles that are universal for all peoples and constant over all time? How is the constitution of a nation related to more general and fundamental cultural traditions, i.e., does the constitution shape the culture or does the culture shape the constitution? How is your view of the proper role of a constitutional court reflected in your analysis? Does your argument depend on the nature and the content of the particular clause, i.e., is comparative analysis more appropriate for some clauses than for other clauses? Does your argument apply transnationally, i.e., would you treat comparative constitutional arguments the same whether you were a member of the Supreme Court of the United States dealing with the constitutional law of another country or whether you were a member of the constitutional court of some other country dealing with the constitutional law of the United States? See generally Christopher A. Whytock, Taking Causality Seriously in Comparative Constitutional Law: Insights from Comparative Politics and Comparative Political Economy, 41 LOY. L.A. L. REV. 629 (2008). 
how "comparative analysis emphatically is relevant to the task of interpreting constitutions and enforcing human rights. ${ }^{, 37}$ That is enough for $\mathrm{me}^{38}$

37 Ginsburg \& Merritt, supra note 27, at 282; see also R. Randall Kelso South Texas College of Law, U.S.A.), Use of International Sources in United States Constitutional Interpretation, International Association of Law Schools Conference on Constitutional Law, Washington, D.C. (Sept. 11-14, 2009), http://www.ialsnet.org/meetings/constit/papers/KelsoRandall(USA).pdf (setting out the various approaches of the Justices); Michel Rosenfeld (Yeshiva University, U.S.A), Principle or Ideology? A Comparativist Perspective on the U.S. Controversy Over Supreme Court Citations to Foreign Authorities, International Association of Law Schools Conference on Constitutional Law, Washington, D.C. (Sept. 11-14, 2009, http:/www.ialsnet.org/ meetings/constit/papers/RosenfeldMichel(USA).pdf (describing the parallel scholarly and juridical debates from different perspectives and ideologies); David Fontana, The Rise and Fall of Comparative Constitutional Law in the Post-War Era, 36 YALE J. INT'L L. 1 (2010) (charting the rise and fall of comparative constitutional law discourse in American legal education).

38 I cannot improve on Professor Howard's curriculum challenge:

[C]omparative constitutional law has been a growth industry in American law schools. Comparativism in constitutional law serves many purposes. It enriches one's study of American constitutional law by adding another dimension to our critique of what the $\mathrm{Su}$ preme Court does. It heightens our sense of the world beyond our national boundaries, useful to lawyers whose firms and clients operate on the international scene, but also to lawyers as world citizens. Comparative studies can also nourish our search for principles of ordered liberty and for theories of a just society.

Will comparative constitutional law contribute to the growth of American constitutional law? We watch with fascination as justices of the Supreme Court debate whether comparative data are legitimate and relevant in defining such concepts of due process of law and cruel and unusual punishment .... What will tomorrow's justices do? That may depend in part on what is taught in today's law school classrooms.

A.E. Dick Howard (University of Virginia, U.S.A.), The Renaissance of Comparative Constitutionalism, International Association of Law Schools Conference on Constitutional Law, Washington, D.C. (Sept. 11-14, 2009), http:/www.ialsnet.org/meetings/constit/papers/Howard DiCKAE(USA).pdf; see also M.N.S. Sellers (University of Baltimore, U.S.A.), Comparative Constitutional Law: A Window into the Fundamental Requirements of a Just Legal Order, International Association of Law Schools Conference on Constitutional Law, Washington, D.C. (Sept. 11-14, 2009), http:/www.ialsnet.org/meetings/constit/papers/SellersMortimer(USA).pdf ("The proper purpose of constitutionalism has been, from the beginning, to advance the common good through law. .. The value of comparative constitutional law arises ... from comparing the efficacy with which the many various constitutional orders in the world realize and advance a just legal order, in the very different political, cultural, regional, historical and other circumstances in which they find themselves."). 


\section{APPENDIX}

\section{LESSON I: JUDICIAL REVIEW}

Chapter 1. Judicial Review

$\S 1$ - 2. Limitations on the Exercise of Judicial Review at 70:

Like rock-and-roll, judicial review is here to stay, with all due respect to Justice Scalia, who declined to comment on Marbury v. Madison, 5 U.S. (1 Cranch) 137 (1803), during his Senate confirmation hearing, because he said the issue might come before the Supreme Court. ANTONIN SCALIA, A MATTER OF INTERPRETATION: FEDERAL COURTS AND THE LAW (1997). However, a noteworthy development in the 1990s was the hard core critique against the Supreme Court's power and performance. Robert Bork, the Reagan nominee who was not confirmed to the Supreme Court and one of the most conservative constitutionalists on the right, and Georgetown University's Mark Tushnet, one of the most liberal constitutionalists on the left, both published book-length arguments against judicial review. ROBERT H. BORK, SLOUCHING TOWARDS GOMORRAH: MODERN LIBERALISM AND THE AMERICAN DECLINE (1996); MARK TUSHNET, TAKING THE CONSTITUTION AWAY FROM THE COURTS (1999). Bork would allow the Supreme Court to continue to decide constitutional cases but would amend the Constitution to authorize Congress to overrule an interpretation of the Constitution by a simple majority vote. Tushnet would go farther to eliminate judicial review in the courts by a constitutional amendment, leaving the task of constitutional interpretation to Congress and populist politics. These prominent heretics, and numerous other scholars and commentators who have joined in the intellectual fray, demonstrate how the dogma of judicial review still remains controversial in the United States. But consider judicial review within a comparative constitutional law perspective.

\section{Required Readings:}

(1) WiLliam E. Nelson, The Worldwide Spread of Judicial Review, in MARBURY $V$. MADISON: THE ORIGINS AND LEGACY OF JUDICIAL REVIEW 104-13 (2000) (TWEN file).

(2) Ran Hirschl, Looking Sideways, Looking Backwards, Looking Forwards: Judicial Review vs. Democracy in Comparative Perspective, 34 U. RICH. L. REV. 415 (2000) (TWEN file). 
Discussion Questions:

- Review the questions in the casebook at page 11-14, particularly question 4 at 12-13.

- What difference has the power of judicial review made in the constitutional history of the United States and other countries? What are its costs and benefits?

- What explains a country's attitudes towards its judicial institutions, i.e., courts, judges, and the exercise of judicial review?

- Are there viable alternatives to the legalization or constitutionalization of rights? Can other institutions of government besides the judiciary define and protect individual rights? What are the relative advantages and disadvantages of the traditional three branches - Legislative, Executive, and Judicial - for interpreting the Constitution?

- How have other countries sought to adjust for the "countermajoritarian" difficulty of the doctrine of judicial review, i.e., the inherent tension between rigid constitutionalism and judicial policymaking, on the one hand, and fundamental democratic values of political participation and representation, on the other?

\section{Further Readings:}

Ran Hirschl, Towards Juristocracy: The Origins and Consequences of the New Constitutionalism (2004).

HERBERT JACOB, ED., COURTS, LAW, AND POLITICS IN COMPARATIVE PERSPECTIVE (1996) (chapter-length discussions of the United States, England, France, Germany, and Japan).

EDWARD MCWHINNEY, SUPREME COURTS AND JUDICIAL LAW-MAKING: CONSTITUTIONAL TRIBUNALS AND CONSTITUTIONAL Review (1986) (compares judicial review in the United States, Canada, India, Germany, France, and Japan).

BARRY STURGESS \& PHILIP CHUBB, JUDGING THE WORLD: LAW AND POLITICS IN THE WORLD'S LEADING COURTS (1988) (examines the highest courts of Australia, New Zealand, Great Britain, Canada, India, Ireland, United States, West Germany, plus the World Court and some other supranational judicial institutions).

Symposium: Judicial Review in the Americas . . . and Beyond, 45 DUQUESNE L. REV. 361 (2007) (interdisciplinary perspectives; particular comparative analysis of Argentina, Canada, Costa Rica, Mexico, Peru, and Venezuela).

Symposium: Comparative Avenues in Constitutional Law, 82 TEX. L. REV. 1653 (2004) (comparing constitutional structures and institutional designs; borrowing among regimes; and constitutional courts in the field of power politics). 
Mauro Capppelletti, The "Mighty Problem" of Judicial Review and the Contribution of Comparative Analysis, 53 S. CAL. L. REV. 409 (1980) (comparative analysis indicates opposing trend lines: European legal systems are moving towards greater roles for courts and judges at the same time that many in the United States are questioning the fundamental idea of judicial review).

David Deener, Judicial Review in Modern Constitutional Systems, 46 AM. POL. SCI. REV. 1079 (1952) (traces the historical acceptance of judicial review as a means for guarding against legislative encroachments on the constitution).

Ran Hirschl, The Political Origins of the New Constitutionalism, 11 IND. J. GLOBAL LEGAL STUD. 71 (2004) (assesses the theories of transformation that purport to explain the globalization of judicial review and individual rights entrenchment).

Symposium, Judicial Review in Latin America, 7 Sw. J. L. \& TRADE AM. 227 (2000) (articles on judicial review in Argentina, Chile, Costa Rica, Cuba, and Mexico).

Michael Troper, The Logic of Justification of Judicial Review, 1 INT'L J. CONST. L. 99 (2003) (explores the fundamental contradictions of judicial review).

Mark Tushnet, Alternative Forms of Judicial Review, $101 \mathrm{MICH}$. L. REV. 2781 (2003) (compares strong and weak versions of judicial review).

\section{LESSON II: TRANSNATIONAL INTERPRETATION}

Chapter 5. The Foreign Affairs Power

\section{$\S 5-2$. Treaties and Executive Agreements at 350:}

In order to interpret the Constitution, even an originalist must find guidance in another time and place. The framers self-consciously and forthrightly borrowed greatly from the constitutional thought of other countries. They were conversant with Aristotle, Cicero, Montesquieu, and Locke, for examples. Yet, the leading proponent of originalism on the High Court today insists "comparative analysis [is] inappropriate to the task of interpreting a constitution." Printz $v$. United States, 521 U.S. 898, 921 n.11 (1997) (Scalia, J., concurring). There is much talk today in the popular press about "globalization" and "transnational" influences, which transcend national boundaries and influence matters of culture and economics. Certainly, the popular culture of the United States is a major influence around the world. Indeed, the process of Americanization has been derisively dubbed "McWorld." But what about constitutional law? Can it be imported 
and exported from one country to another or is a particular country's fundamental law unique - exclusive and self-contained to that country? What are the sources of constitutional law, i.e., when we refer to the Constitution to what are we referring? Only the four corners of the text? History and tradition? What about transnational legal documents, like the United Nation's Declaration of Human Rights? How does your answer fit into our study of the treaty power?

Required Readings:

(1) Knight v. Florida, 528 U.S. 990 (1999).

(2) Clair L'Heureux-Dube, The Importance of Dialogue: Globalization and the International Impact of the Rehnquist Court, 34 TULSA L. J. 15 (1998) (34 TLSLJ 15).

\section{Discussion Questions:}

- What, if any, are the economic assumptions underlying the Constitution of the United States? What, if any, are its underlying socio-political assumptions? Temporally, how can it be that an eighteenth century document is still operative in the twenty-first century?

- Assuming that the Constitution functions satisfactorily and effectively in the United States, would it function the same way if it were adopted by another country? Are there some provisions of the Constitution that are idiosyncratic to the United States and others that are universal?

- Who makes the better argument - Justice Thomas concurring or Justice Breyer dissenting in the denial of the writ of certiorari in Knight $v$. Florida - on the issue whether the jurisprudence of other countries should inform how the Supreme Court would decide the issue whether a defendant can take advantage of appellate and collateral procedures and then complain about the resulting delay of his execution?

- According to Clair L'Heureux-Dube, Puisne Justice of the Supreme Court of Canada, how do courts in different countries consider each others' judgments and what has been the role of the Rehnquist Court within what she calls the "new global judicial community?"

- Following Western political philosophy, the United States distinguishes political entitlements we call civil rights and civil liberties that are protected by the Constitution proper from other entitlements to government benefits that are provided by the state. Thus, there is a right to free speech but there is only a statutory entitlement to public assistance or welfare. Are these categories separate and distinct? What does this distinction say about the Constitution and the social traditions of the United States? Furthermore, for some fundamental 
rights, like the right to counsel, the state has a duty to subsidize the right if a person is indigent, but for other fundamental rights, like the right of privacy that figures in a woman's autonomy to terminate her pregnancy, the state does not have a duty to subsidize the right, even if the abortion is necessary to protect the health and life of the woman. Do these distinctions make sense in the context of background normative principles in constitutional law?

\section{Further Readings:}

Roger P. Alford, In Search of a Theory for Constitutional Comparativism, 52 UCLA L. REV. 639 (2005) (presents four classical constitutional theories - originalism, natural law, majoritarianism, and pragmatism - and addresses the propriety of comparativism under each theory).

Robert S. Barker, Constitutionalism in the Americas: A Bicentennial Perspective, 49 U. PITT. L. REV. 891 (1988) (emphasizes the Constitution as an inter-American document that has influenced most Latin American constitutions).

William J. Brennan, The Worldwide Influence of the United States Constitution as a Charter of Human Rights, 15 NOVA L. REV. 1 (1991) (discusses the influence of the Constitution and American judicial review on the constitutional law of other countries).

Pat K. Chew, The Rule of Law: China's Skepticism and the Rule of People, 20 OHIO ST. J. ON DISP. RESOL. 43 (2005) (explores alternative cultural assumptions about the rule of law in the theoretical debate between legal formalism and cultural norms).

Sujit Choudhry, Globalization in Search of Justification: Toward a Theory of Comparative Constitutional Interpretation, 74 IND. L. J. 819 (1999) (describes how comparative constitutional law has assumed a central role in constitutional law around the world).

David Fontana, Refined Comparativism in Constitutional Law, 49 UCLA L. REV. 539 (2001) (argues that a moderate, workable practice of using comparative constitutional law is consistent with both the original understanding of the Constitution and the historical practice of the Supreme Court).

Ruth Bader Ginsburg, Looking Beyond Our Borders: The Value of a Comparative Perspective in Constitutional Adjudication, 40 IDAHO L. REV. 1 (2003) (discusses "why we should both lead and learn from others" regarding judicial review for constitutionality).

Mary Ann Glendon, The Forgotten Crucible: The Latin American Influence on the Universal Human Rights Idea, 16 HARV. HUM. RTS. J. 27 (2003) (explores the role and influence of Latin American models on the Universal Declaration of Human Rights). 
Heinz Klug, Model and Anti-Model: The United States Constitution and the "Rise of World Constitutionalism", 2000 WISC. L. REV. 597 (discusses and evaluates the place of the United States Constitution in the context of the globalization of constitutionalism).

Joan L. Larsen, Importing Constitutional Norms from a "Wider Civilization": Lawrence and the Rehnquist Court's Use of Foreign and International Law in Domestic Constitutional Interpretation, 65 OHIO ST. L. J. 1283 (2004) (explores the various ways justices on the Rehnquist Court have used foreign and international law to interpret the U.S. Constitution).

David S. Law, Generic Constitutional Law, 89 MiNN. L. REV. 652 (2005) (explores why judges in different countries are increasingly applying somewhat similar constitutional doctrines and reasoning in somewhat similar circumstances and whether academics and judges should embrace or resist this development of a "generic constitutional law").

Richard B. Lillich, The United States Constitution and International Human Rights Law, 3 HARV. HUM. RTS. 53 (1990) (describes how the United States has contributed significantly to the development of international human rights but criticizes the Supreme Court for making little use of international human rights documents either directly or in interpreting the Constitution).

ROBERT L. MADDEX, THE IlluSTRATED DictionaRY OF CONSTITUTIONAL CONCEPTS (1996) (international and comparativist reference for constitutional terms and concepts).

Cody Moon, Comparative Constitutional Analysis: Should the United States Supreme Court Join the Dialogue?, 12 WASH. U. J.L. \& POL'Y 229 (2003) (proposes that the Supreme Court adopt a selective practice of comparative constitutional analysis).

Matthew S. Raalf, Note, A Sheep in Wolf's Clothing: Why the Debate Surrounding Comparative Constitutional Law is Spectacularly Ordinary, 73 FORDHAM L. REV. 1239 (2004) (seeks to reconceptualize the debate in terms of the underlying constitutional theories).

John C. Reitz, How to Do Comparative Law, 46 AM. J. COMP. L. 617 (1998) (describes a "comparative method" and identifies the most important characteristics of good comparative scholarship).

Michel Rosenfeld, Constitutional Migration and the Bounds of Comparative Analysis, 58 N.Y.U. ANN. SURV. AM. L. 67 (2001) (argues that comparative constitutional analysis has become necessary and unavoidable given the migration of constitutional ideas and the transplantation of constitutional norms across national boundaries).

Mark Tushnet, The Possibilities of Comparative Constitutional Law, 108 YALE L. J. 1225 (1999) (offers a systematic approach to the 
possibility of learning from the constitutional experience of other countries in the process of interpreting the Constitution).

Symposium, Constitutional Borrowing, 1 INT'L J. CONST. L. 181 (2003) (various scholars from various countries examine the phenomenon of "borrowing" - comparative constitutional law).

Symposium: Contextuality \& Universality: Constitutional Borrowing on the Global Stage, 1 U. PA. J. CONST. L. 173 (1998) (various scholars explore the practice of borrowing and its implications for constitutionalism).

\section{LESSON III: AFFIRMATIVE ACTION}

Chapter 8. Equal Protection

\section{$\S 8-2$. Suspect Classes and Other Classifications at 789:}

The International Covenant on Civil and Political Rights (CCPR) is a fundamental human rights treaty that was adopted by the General Assembly of the United Nations in 1966 and was ratified by the United States in 1992. International Covenant on Civil and Political Rights, Dec. 16, 1966, 999 U.N.T.S. 171, http://www2.ohchr.org/ english/law/ccpr.htm. Article 2 contains a general norm against any state discrimination based on "race, colour, sex, language, religion, political or other opinion, national or social origin, property, birth or other status" in regard to the rights recognized in the Covenant. Id. art. 2. Article 26 specifically provides for an international right to the equal protection of the laws:

All persons are equal before the law and are entitled without any discrimination to the equal protection of the law. In this respect, the law shall prohibit any discrimination and guarantee to all persons equal and effective protection against discrimination on any ground such as race, colour, sex, language, religion, political or other opinion, nation or social origin, property, birth or other status.

Id. art. 26.

A second important treaty, the International Convention on the Elimination of All Forms of Racial Discrimination (CERD) was adopted by the General Assembly of the United Nations in 1965 and was ratified by the United States in 1994 . International Convention on the Elimination of All Forms of Racial Discrimination, Mar. 7, 1966, 660 U.N.T.S.195, http://www2.ohchr.org/english/law/cerd.htm. In Article I "racial discrimination" is defined as 
any distinction, exclusion, restriction or preference based on race, colour, descent, or national or ethnic origin which has the purpose or effect of nullifying or impairing the recognition, enjoyment or exercise, on an equal footing, of human rights and fundamental freedoms in the political, economic, social, cultural or any other field of public life.

Id. art. 1(1).

Article I goes on to authorize and allow for "special measures:"

Special measures taken for the sole purpose of securing adequate advancement of certain racial or ethnic groups or individual requiring such protection as may be necessary in order to ensure such groups or individuals equal enjoyment of exercise of human rights and fundamental freedoms shall not be deemed racial discrimination, provided, however, that such measures do not, as a consequence, lead to the maintenance of separate rights for different racial groups and that they shall not be continued after the objectives for which they were taken have been achieved.

Id. $\operatorname{art.1(4).}$

A third important treaty, the Convention on the Elimination of All Forms of Discrimination Against Women (CEDAW) was adopted by the General Assembly of the United Nations in 1979 and was ratified by the United States in 1980. Convention on the Elimination of All Forms of Discrimination Against Women, Dec. 18, 1979, 1249 U.N.T.S. 13, http://www2.ohchr.org/english/law/cedaw.htm. In Article 1 , "discrimination against women" is defined as

distinction, exclusion or restriction made on the basis of sex which has the effect or purpose of impairing or nullifying the recognition, enjoyment or exercise by women, irrespective of their marital status, on a basis of equality of men and women, of human rights and fundamental freedoms in the political, economic, social, cultural, civil or any other field.

Id. art. 1.

Article 2 generally condemns discrimination against women "in all its forms," Id. art. 2, however, Article 4 specifically provides:

Adoption by States Parties of temporary special measures aimed at accelerating de facto equality between men and women shall not be considered discrimination as defined in this Convention, but shall in no way entail as a consequence the maintenance of unequal or separate standards; these measures shall be discon- 
tinued when the objectives of equality of opportunity and treatment have been achieved.

Id. art. 4.

Signatory states must reconcile these international agreements with the constitutional law of their country and their domestic policies. For example, read these treaties side-by-side with the Fourteenth Amendment and the U.S. Supreme Court decisions on the subject of affirmative action for race and gender.

\section{Discussion Question:}

- In the United States, "special measures" are usually called "affirmative action" or "reverse discrimination." In the European Community, the term is "positive action." The programs are known in India as "compensatory discrimination." But no matter what one labels these governmental programs, the question of international law is whether the programs are permitted under the UN treaties and the domestic constitutional law of the relevant country. Answer this question from the two different comparative constitutional law perspectives: first from the perspective of the United States - based on our study of affirmative action - and second from the different perspective of one of the following: Canada, China, the European Community, Germany, India, or South Africa. Choose your second perspective and then read at least one applicable article from the following list to help you answer the second part of the question:

M. Varn Chandola, Affirmative Action in India and the United States: The Untouchable and Black Experience, 3 IND. INT'L \& COMP. L. REV. 101 (1992) (India and castes).

Adil Hassim, Affirmative Action Policies in the United States and South Africa: A Comparative Study, 2000 ST. LOUIS-WARSAW TRANSATLANTIC L.J. 119 (South Africa and race).

Barry Sautman, Affirmative Action, Ethnic Minorities and China's Universities, 7 PAC. RIM L. \& POL'Y J. 77 (1998) (China and ethnicity).

Jason Morgan-Foster, Note, From Hutchins Hall to Hyderbad and Beyond: A Comparative Look at Affirmative Action in Three Jurisdictions, 9 WASH. \& LEE RACE \& ETHNIC ANC. L. J. 73 (2003) (race/United States and gender/Europe and caste-India).

Christopher D. Totten, Constitutional Precommitments to Gender Affirmative Action in the European Union, Germany, Canada and the United States: A Comparative Approach, 21 BERKELEY J. INT'L L. 27 (2003) (United States, Canada, Germany, and European Union and gender). 
Ruth Bader Ginsburg \& Deborah Jones Merritt, Affirmative Action: An International Human Rights Dialogue, 21 CARDOZO L. REV. 253 (1999) (seeks to reconcile and legitimate affirmative action with the United Nations Universal Declaration of Human Rights).

\section{Further readings:}

THE GENDER OF CONSTITUTIONAL JURISPRUDENCE (Beverley Baines \& Ruth Rubio-Marin, eds., 2005) (comparing the constitutions of Australia, Canada, Colombia, Costa Rica, France, Germany, India, Israel, South Africa, Spain, Turkey, and the United States).

Symposium on Affirmative Action: An International Perspective on a Global Dilemma, 36 CONN. L. REV. 649 (2004) (articles about the United States, South Africa, India, Brazil, and international human rights law).

Danielle Caruso, Limits of the Classic Method: Positive Action in the European Union After the New Equality Directives, 44 HARV. INT'L L. J. 331 (2003) (considers the issues within the broader context of the evolution of European constitutionalism).

Rebecca L. Case, Note, Not Separate But Not Equal: How Should the United States Address Its International Obligations to Eradicate Racial Discrimination in the Public Education System?, 21 PENN. ST. INT'L L. REV. 205 (2002) (analyzes how treaties and conventions might be applied to public schools).

Tanya Katerí Hernández, Multicultural Matrix: the Role of Race Ideology in the Enforcement of Antidiscrimination Laws, a United States - Latin America Comparison, 87 CORNELL L. REV. 1093 (2002) (examines the role and function of race ideology in the enforcement of antidiscrimination laws in the United States and Latin America and argues for a more global focus).

F. Michael Higginbotham, Affirmative Action in the United States and South Africa: Lessons from the Other Side, 13 TEMP. INT'L COMP. L.J. 187 (1999) (South Africa and race).

James P. Sterba, Completing Thomas Sowell's Study on Affirmative Action and Then Drawing Different Conclusions, 57 STAN. L. REV. 657 (2004) (reviewing THOMAS SOWELL, AFFIRMATIVE ACTION AROUND THE WORLD: AN EMPIRICAL STUDY (2004)).

Thomas Trelogan, Steve Mazurana \& Paul Hodapp, Can't We Enlarge the Blanket and the Bed?: A Comparative Analysis of Positive/Affirmative Action in the European Court of Justice and the United States Supreme Court, 28 HASTINGS INT'L COMP. L. REV. 39 (2004) (comparing the arguments and analysis of European positive action and American affirmative action for women).

Sean Pager, Strictness and Subsidiarity: An Institutional Perspective on Affirmative Action at the European Court of Justice, 26 B.C. 
INT'L \& COMP. L. REV. 35 (2003) (describes how the ECJ has taken an "American approach" to affirmative action that is out of keeping with its supranational role and contrary to the principle of judicial subsidiarity towards the national judiciaries of member states).

Sean Pager, Equality and the European Union, 32 GA. J. INT'L COMP. L. 73 (2004) (examines the new comprehensive initiatives of the EU regarding human rights and anti-discrimination).

Jordan J. Paust, Race-based Affirmative Action and International Law, 18 MICH. J. INT'L L. 659 (1997) (discusses the international law, treaty-based acceptability of affirmative action programs).

Robert Perkovich \& Reena Saini, Women's Rights in Cuba: "Mas O Menos," 16 EMORY INT'L L. REV. 399 (2002) (explores gender equality issues from the perspectives of politics, ideology, and culture).

Carol Daugherty Rasnic, The U.S. Supreme Court on Affirmative Action: Are Some of Us "More Equal" than Others! (With Some Comparisons to Post-Good Friday Agreement Police Hiring in Northern Ireland), 7 SCHOLAR 23 (2004) (compares the most recent Supreme Court cases in higher education to provision in the Agreement that police be hired $50 \%$ Catholic and $50 \%$ Protestant).

Compare Brad R. Roth, The CEDAW as a Collective Approach to Women's Rights, 24 MICH. J. INT'L L. 187 (2002), with Rhonda E. Howard-Hassman, (Dis) Embedded Women, 24 MICH. J. INT'L L. 227 (2002) (debating which international legal approach more effectively protects women's rights, the collective or the individual).

Kendall Thomas, The Political Economy of Recognition: Affirmative Action Discourse and Constitutional Equality in Germany and the U.S.A., 5 COLUM. J. EuR. L. 329 (1999) (Germany and gender).

Todd Joseph Koback, Note, The Long, Hard Road to Amsterdam: Effects of Kalanke v. Freie Hansestadt Bremen and the Treaty of Amsterdam on Positive Action and Gender Equality in European Community Law, 17 WISC. INT'L L.J. 463 (1999) (European Community and gender).

\section{LESSON IV: REPRODUCTIVE RIGHTS}

Chapter 8. Equal Protection

\section{$\S 8-3$. Fundamental Rights at 943 :}

Prominent American constitutionalists have debated the value of comparative constitutional law in the area of reproductive rights, among them two Harvard professors: Mary Ann Glendon and Laurence H. Tribe. Compare MARY ANN GLENDON, ABORTION AND 
DIVORCE LAW IN WESTERN LAW: AMERICAN FAILURES, European Challenges (1989), with Laurence H. TRIBE, ABORTION: THE ClASH OF ABSOLUTES (1992). Professor Glendon argues in favor of the European approach, which she describes as more communitarian and more nuanced to take into account both sides of the issue, what we call the "Pro-life" side and the "Prochoice" side. She criticizes the fact that abortion policy in the United States was not worked out in the legislative process but rather was decreed by the Supreme Court in a series of decisions that not only rendered existing state statutes unconstitutional but also severely limited the scope of any subsequent state regulations. She believes that, if the states had been left alone to legislate, most legislatures would have followed the trend in the decade before the Supreme Court constitutionalized the subject and their statutes would resemble most European statutes which permit abortions but require medical findings and counseling. Professor Tribe disagrees to criticize the European statutes as amounting to either an empty promise for the "Prochoice" side or a false promise for the "Pro-life" side. He insists that the European approach of different countries taking different approaches to abortion should not be allowed among the fifty states because it would compromise the American norm of equality and undermine the entire enterprise of defining and protecting individual rights. Thus, the abortion issue and reproductive rights more generally are as contested an area of comparative constitutional law as they are for constitutional law within the United States.

Required Reading (read one of these two selections in the excerpt from the VICKI C. JACKSON \& MARK TUSHNET, COMPARATIVE CONSTITUTIONAL LAW (1st ed. 1999)) (multiple pdf files are on the Westlaw TWEN page):

Morgentaler, Smoling and Scott v. The Queen, 1 S.C.R. 30 (Supreme Court of Canada 1988) (JACKSON \& TUSHNET, supra, at 77-113),

or

The Sequence of Abortion Decisions by the German Courts (West German Federal Constitutional Court 1975 \& German Constitutional Court 1993) (JACKSON \& TUSHNET, supra, at 115-40).

\section{Discussion questions:}

- Can you distinguish between matters of public policy that belong in the legislative branch and other matters of constitutional law that belong in the judicial branch? Does the Constitution provide 
clear distinctions between them? Is there a dividing line between law and politics?

- Based on your reading, analyze and compare the constitutional law of either Canada or Germany with what you learned about the constitutional law of the United States on the subject of abortion.

- Hypothetical: suppose a state passes a Zero Population Growth Act, patterned after China's "One Child Rule," which imposes a twochild limitation on everyone, i.e., every person can have only two biological children. The legislature's stated purposes are to preserve the general quality of life in the state, to reduce the increase in demand for state government services, and to reduce environmental degradation. A one-time fine or "tax" of $\$ 1000$ will be imposed on anyone for every child over the limit. This is a lifetime limitation that applies no matter how often a person is married and whether or not the child survives. Would the measure be constitutional? What is the proper constitutional analysis? Would your conclusion vary from the United States to Canada to Germany?

Further Readings:

Diana D.M. Babor, Population Growth and Reproductive Rights in International Human Rights Law, 14 CONN. J. INT'L L. 83 (1999).

Donald L. Beschele, Judicial Review and Abortion in Canada: Lessons for the United States in the Wake of Webster v. Reproductive Health Services, 61 U. CoLO. L. REV. 537 (1990).

Sarah Davis, Note, United States, Germany, and South Africa: Constitutional and Judicial Decisions on Abortion - Testing Judicial Globalization, 16 TEMP. INT'L \& COMP. L. J. 170 (2002).

Deborah Goldberg, Developments in German Abortion Law: A U.S. Perspective, 5 UCLA WOMEN's L. J. 531 (1995).

Berta E. Hernandez, To Bear or Not to Bear: Reproductive Freedom as an International Human Right, 17 BROOK. J. INT'L L. 309 (1991).

Crene T. Kendrick, Note, The Illegality of Abortion in Mexico, 39 STAN. J. INT'L L. 125 (2003).

Richard E. Levy \& Alexander Somek, Paradoxical Parallels in the American and German Abortion Decisions, 9 TUL. J. INT'L \& COMP. L. 109 (2001).

Maureen C. McBrien, Ireland: Balancing Traditional Domestic Abortion Law With Modern Reality and International Influence, 26 SUFFOLK TRANSNAT'L L. REV. 195 (2002).

Gerald L. Neuman, Casey in the Mirror: Abortion, Abuse, and the Right to Protections in the United States and Germany, 43 AM. J. COMP. L. 273 (1995). 
Charles Stanley Ross, The Right of Privacy and Restraints on Abortion Under the "Undue Burden" Test: A Jurisprudential Comparison of Planned Parenthood v. Casey with European Practice and Italian Law, 3 IND. INT'L \& COMP. L. REV. 199 (1993).

Richard Stith, New Constitutional and Penal Theory in Spanish Abortion Law, 35 J. AM. J. COMP. L. 513 (1987).

Katarina Tomasevski, European Approaches to Enhancing Reproductive Freedom, 44 AM. U. L. REV. 1037 (1995).

For FindLaw's links to various on-line documents from the People's Republic of China, including the constitution and the 1979 Tian An Men Square Declaration of Human Rights, see generally http://www.findlaw.com/12international/countries/cn.html.

The BBC has posted links to the abortion policies of member states of the European Union: http://news.bbc.co.uk/1/hi/world/ europe/1869009.stm. 